\title{
A metric to assess the competitive position of airlines and airline groups in the intra-European air transport market
}

\author{
Sven Maertens \\ German Aerospace Center (DLR), Air Transport and Airport Research, \\ Linder Höhe, Cologne, Germany \\ Phone: ++49-2203-601-2596 \\ Fax: ++49-2203-601-12594 \\ Email: sven.maertens@dlr.de
}

JEL classification:

L93,

R48

D40

Keywords:

Airline competition

Airline network competition

Market power

Competitive position

European airlines

Leisure airlines

Air transport market

Airline groups

Low cost carriers

Low cost airlines

Hub-and-spoke

Herfindahl-Hirschman index

\begin{abstract}
:
A strong competitive position can not only be regarded as a key success factor for firms, but may also indicate market power. As with operators of other long-distance transport modes, like e.g. train or coach operators, assessing an airline's overall competitive position is not trivial: This is because airlines serve many different, direct and indirect origin-destination (OD) markets between which competition intensity can vary immensely. Hence, airline (or rather airline group) networks compete against each other, meaning that "typical", e.g. HHIbased competition assessments at, e.g., the national, airport or direct route levels will not be sufficient to get a full picture. This paper presents a modelling approach for an indicator for the individual competitive positions (CP) of airlines and airline groups at the network level. An application to the intra-European market, based on OD data for 2015, indicates a quite comfortable competitive position for low cost carriers like Ryanair, WIZZ Air, FlyBE or Volotea, followed by the major airline groups (Lufthansa, Air France-KLM, IAG) which focus on hub and spoke networks along some low cost activities. The weakest CP's within our sample of the 30 largest European airlines and airline groups are calculated for leisure airlines like Monarch, which recently filed for bankruptcy.
\end{abstract}




\section{Introduction and objective}

From a business perspective, high market shares and hence a strong competitive position (CP) can be regarded as key success factors for firms (Buzzell et al, 1975). However, they can also indicate market power and a potential need for regulation. The term "competitive position" can be defined as the position a firm occupies in the whole relevant market, relative to its competitors (see e.g. Veldhuis, 1997). ${ }^{1}$

In public passenger transportation, monopolization, market power and regulation intensity can highly vary between and even within transport modes and (world) regions. While market access and pricing in urban and regional transportation are usually regulated, there are a number of examples for major deregulation efforts in long-distance transport. These include intercity coach deregulation in the UK in 1980 (later followed by similar efforts undertaken in other European countries, such as Norway and Sweden in the 1990s, and eventually Italy, Germany and France in the 2010s - for an overview see e.g. Grimaldi et al, 2017), and the stepwise liberalization of EU passenger rail transport which shall result in an open market from 2020 (EU, 2016).

Driven by the 1978 US Airline Deregulation Act, ${ }^{2}$ global air transport can be regarded as a forerunner in longdistance transport market deregulation. The most prominent example for international air transport market liberalization certainly stems from Europe where a single (EU) market for air transport was completed in 1997 and later further extended to neighbouring countries, forming the so-called European Common Aviation Area (EU, 2006). Without doubt, these new policies have led to an - overall - more competitive airline market in Europe, which is characterized by more routes and lower fares (e.g. Burghouwt and de Wit, 2015; Lieshout et al, 2016). One major driver of this was the emergence and rise of low cost carriers (LCC) which put a lot of competitive pressure on sometimes slowly-reacting legacy carriers (see e.g. Dobruszkes, 2013; Doganis, 2006). However, competition intensity even varies within this deregulated European air transport market, as many routes and origin-destination (OD) markets are still monopolistic (Dobruszkes, 2009; Burghouwt and de Wit, 2015).

To assess the degree of competition hence requires appropriate market definition (see e.g. Baker, 2007), which is not a straightforward task. Competition analyses in air transport - as in other transport markets - are usually based on market structure assessments e.g. at isolated airport or national levels, or for selected (direct) routes. Typical concentration measures that are applied to the firms' market shares (usually in terms of frequencies or seats) include the traditional Hirshman-Herfindahl index or, less often, the GINI coefficient or entropy.

Such approaches, though, can fall short when it comes to the assessment of the overall, i.e. network-wide, competitive position of a particular carrier. The reason is that airlines serve many different (direct and indirect) origin-destination (sub-)markets between which competition levels will vary immensely, making "THE" overall competitive position of a carrier difficult to assess.

This paper presents a modelling approach for an indicator for the overall competitive positions of airlines and airline groups at the network level, and applies it to the intra-European air transport market. The approach considers actual market shares on each single OD and the relative contribution of each OD to the airline's or airline group's total passenger volume, indicating the average network-wide extent to which the airline or airline group is contested by other (groups of) carriers. To our best knowledge, this perspective was not yet taken in any earlier paper.

Hence, the methodology might provide useful, additional information e.g. for policy-makers or regulators, and probably also for analysts or e.g. fund managers, which might look for strong carriers to invest in. Its application is not limited to intra-European air transport market but could also be conducted for other regions or more specific questions, such as mergers.

The paper is structured as follows: Section 2 discusses the relevant literature on competition in the airline market, with a special focus on Europe, and on the use of measures like HHI and their limitations when it comes to the assessment of an airline's competitive position. In Section 3, our methodology and the dataset for Europe are presented. Section 4 then reports on the key results for airlines and airline groups in the intra-European air transport market, followed by some concluding remarks in Section 5.

\footnotetext{
${ }^{1}$ Other authors may apply different definitions, such as the way a product is perceived by the customers (e.g. Bowman and Faulkner, 1994).

${ }^{2}$ See Airline Deregulation Act 49 USC 1301 of 1978, available online at: https://www.gpo.gov/fdsys/pkg/STATUTE-92/pdf/STATUTE-92Pg1705.pdf.
} 


\section{Background and literature review}

Monopoly regulation may have to be applied to dominant firms that are steadily immune from any competitive market forces and hence in the position to raise prices or lower product qualities without losing their customers to other firms (Williamson, 1972). By implication, firms without noteworthy market power in a relevant market segment should, if at all, only be regulated with care as regulatory costs could quickly exceed the intended benefits and cause a net decline in welfare.

Monopolisation and resulting market power can be an issue in many long-distance passenger transport markets, including air transport, and here especially in some of the upstream markets. The most relevant example is the air traffic control sector, where each airspace block is operated by a "regional monopoly". Hence, airlines cannot choose between different ATM providers although they may have to deal with several providers along a given route (Button and McDougall, 2006). More diverse with regard to monopolization is the airport landscape. The market power of airport operators depends on various factors such as isolated versus overlapping catchment areas and resulting airport leakage effects, alternative hubs, or the degree of airline countervailing power (see e.g. Barrett, 2000; Button, 2010; Fuellhart, 2007; Lian and Rønnevik, 2011; and Maertens, 2012).

In contrast, downstream the value chain, at airline level, a far-reaching liberalization of markets is widely believed to have increased competition, be it from competing carriers on exactly the same routes ("route competition"), from and/or to alternative airports (Dobruszkes, 2009), or from alternative indirect connections (Alderighi et al, 2005; Pels, 2008). In addition, air transport services may face intermodal competition from other modes of transport, such as high-speed rail (see e.g. D'Alfonso et al, 2016, and the literature cited there), or, in the case of holiday traffic, even from routes to completely different destinations as leisure travellers might often be willing to fly to another destination than the originally envisaged one (Socorro et al, 2018). The latter two issues are not further tackled in this paper.

A topical example for increasing indirect, i.e. "via-hub" competition on long haul markets is the rise of the Gulf carriers (Grimme, 2011; Grosche and Klophaus, 2015; O'Connell and Bueno, 2016) - or rather "BoGu" ("Bosporus-Gulf") or "ChiBoGu" ("China-Bosporus-Gulf") carriers, to also pay tribute to the fast growing airlines from Turkey and China. All these carriers provide travellers with additional indirect route options between the "Western World" and places in the "Eastern Hemisphere" (Middle East, South-East Africa, Asia, Oceania).

In the EU, internal market liberalization was completed in 1997, allowing community carriers to freely select routes and fares (EU, 1992). Neighbouring countries, such as the Balkan states, Norway and Iceland, followed in 2006, leading to the formation of the European Common Aviation Area (ECAA) (EU, 2006). The new policy regime paved the way for a more competitive air transport market which is now characterized by generally more routes and lower fares, mainly driven by the emergence and subsequent growth of LCC like Ryanair, EasyJet, Wizz Air, Vueling or Norwegian (Dobruszkes, 2013). All in all, between 2006 and 2015, the movement share of the LCC sector in intra-European air traffic grew from $19 \%$ to $30 \%$, representing some 45,000 weekly departures (Maertens et al, 2016). At first sight, these large numbers, and the huge number of almost 300 different airlines operating in Europe, ${ }^{3}$ would hint at generally high levels of competition and hence relatively low degrees of market power.

However, airport choice and network structure of many LCC have developed diversely: In the "early" postderegulation days, the most archetypical LCC like Ryanair or Wizz Air put a strong focus on providing alternative travel options from underserved secondary airports, including former military airfields. By this, they usually avoided any head-to-head competition with established airlines or other budget carriers. ${ }^{4}$ As a result, despite many new market entries, monopolies or duopolies at the route level did - in some cases - even increase although the EU air transport market as a whole got more competitive (Dobruszkes, 2009; Burghouwt and de Wit, 2015).

\footnotetext{
${ }^{3}$ As of 10 November, 2017, Flight Global's fleet analyser database revealed 285 operating airlines for Europe (excluding Belarus, Greenland, Russia, Turkey and Ukraine).

${ }^{4}$ Easyjet, Germanwings or Buzz behaved slightly differently as they also served a number of established, major airports from the beginnings on
} 
In the more recent past, then, direct route and airport competition by LCC has increased, even at some of the largest hubs like Amsterdam, Frankfurt, Madrid, Paris or Rome. ${ }^{5}$ Burghouwt and de Wit (2015) refer to this development as the fourth developmental phase following EU air transport liberalization.

Despite this recent trend, we can still identify air transport market segments that tend to be characterized by only limited degrees of competition:

- $\quad$ E.g. due to slot constraints, some airports are dominated by one or few airlines and/or are not yet served by a noteworthy number of LCC (e.g. London Heathrow, Zurich...). The hub carriers operating there are supposed to have a strong market position in the local, direct flight market, where they are likely able to charge "hub premiums" - an issue which was discussed controversially in the literature: While some authors found empirical evidence for hub premiums stemming (partly) from market power (e.g. Borenstein, 1992; Evans and Kessides, 1993; Lijesen et al, 2001), others explain higher fares charged by hub carriers for flights from their hubs with e.g. higher service levels rather than market power (e.g. Dresner and Windle, 1992).

- A number of nonstop routes are served by one or two carriers only, which are often even (alliance) partners or airlines under the same ownership. A good example is the market within and between Germany, Switzerland, Austria and Belgium, which is now almost controlled by the Lufthansa Group.

- In international air traffic, a number of direct country-pair markets are still monopolistic or duopolistic as many restrictive bilateral air service agreements still restrict capacities.

- And there are even cases without competition from or between indirect routings. E.g., the airport of Graz (Austria) is dominated by feeder services to hubs of the Lufthansa Group (Frankfurt, Vienna...), meaning that indirect routings from most places to Graz cannot be considered to be in competition with each other.

In brief, airlines in Europe serve many different "submarkets" with varying degrees of competition (Obermayer et al, 2013). Considering this, it is not trivial to assess an airline's "overall" competitive position. A quite simple approach is to look at overall airline market shares at e.g. the airport, regional or national levels. Such approaches do, however, not consider the actual degrees of competition in all relevant OD markets. For example, the competitive position of airline $\mathrm{A}$ on a relation from $\mathrm{O}$ to $\mathrm{D}$ will not only depend on its own market share on the direct route from $\mathrm{O}$ to $\mathrm{D}$ relative to any competitors operating on the same route, but also on other airlines' indirect supply via one or more hubs $\mathrm{H}_{\mathrm{i}}$ - yet not counting above-mentioned competition from alternative airports and routes to alternative destinations, or from other modes of transport. Borenstein (1992) hence already argued that "measures of national concentration" are just "convenient reference points". Also common are papers that assess the level of competition in air transport markets at e.g. the national, regional, direct route or airport levels, employing indicators like the Hirshman-Herfindahl index (HHI) (e.g. Dresner et al, 1996; Detzen et al, 2012; or lately Lieshout et al, 2016) which is defined as the sum of the squares of the market shares of the individual firms in the market regarded as relevant, and hence may take values between close to zero (many firms with small market shares each) and one (one firm holding a market share of 1). The larger the HHI is, the higher the concentration. In addition, other measures that are sometimes used to assess the concentration in the air trapsort sector include the GINI coefficient (e.g. Reynolds-Feighan, 2001) and entropy (e.g. Frenken et al, 2004, or Dobruszkes, 2009).

There is also anecdotal evidence that the consideration of competition at the nonstop route level only was a basis for legal decisions, at least in Germany. For example, in the Lufthansa-Eurowings merger case, the German Federal Cartel Office defined only the German domestic market as relevant and not all the different indirect markets from German spokes via hubs to the rest of the world (Bundeskartellamt, 2001). Another example was an obligation (set by the same authority) for Lufthansa not to undercut fares by newcomer Germania on the route Frankfurt-Berlin (FAZ.net, 2002). And also in the current discussions of the competitive impacts of the Air Berlin bankruptcy, the public eye is mainly on the isolated domestic, direct route level (e.g. Berliner Morgenpost, 2017).

While the application of concentration measures like HHI is a straightforward way to describe the competitive situation in a pre-defined market, they cannot be used to assess the individual competitive position of firms that like airlines - operate in many different sub-markets with varying degrees of competition. Hence, to our best knowledge, this paper takes a new approach in providing an approach for the assessment of the competitive position of European airlines at their total network level, considering actual competition in terms of market shares on all direct and indirect OD markets they serve.

\footnotetext{
${ }^{5}$ See current schedules and e.g. Dziedzic and Warnock-Smith (2016) and Dobruszkes et al (2017).
} 
This approach can make an interesting and useful new dimension e.g. for regulators and policymakers when e.g. judging on a particular airline's market power, or for analysts and investors. The idea behind this network perspective is not entirely new, but earlier papers either tackled the role of network competition from a theoretical or conceptual perspective (e.g. Adler, 2001; Alderighi et al, 2005) or focused at the US domestic market only. An example for the latter is Borenstein (1992) who showed that HHI-concentration at the city-pair route level (incl. indirect routings) had decreased following the US deregulation act as airlines had switched their business models to hub\&spoke network operations that tend to compete at the city-pair level. Veldhuis (1997) also looked at network competition, albeit from the airport perspective. He applied a (supply-based) connectivity model to assess the relative connectivity performance, or rather the connectivity potential, of airports. This paper, in contrast, takes an airline perspective and bases the approach on actual airline passenger flows, i.e. on actual demand patterns.

\section{Methodology and data}

An airline's (relevant) market comprises all OD relations it actually sells tickets for, and hence not only the nonstop routes or a particular airport, region or country. Otherwise, large shares of the total traffic volumes of network carriers that fly passengers over their hubs would not be considered. We assume that airline $i$ would have the strongest possible competitive position $\left(\mathrm{CP}_{\mathrm{i}}\right)$ if it was free from any intra-modal competition on all of its (sub-)markets, while it would be heavily contested if all its individual, OD-specific market shares were small. Relevant ODs are usually defined as airport pairs or, if alternative airports serving the same or a similar catchment area are regarded as interchangeable by the customers, as city pairs. As explained in the literature review section, competition from other modes of transport and from flights to other destinations can also have a competitive impact on airline $\mathrm{i}$, but this is not further considered in this paper.

We define the overall competitive position $\left(\mathrm{CP}_{\mathrm{i}}\right)$ of carrier $\mathrm{i}$ at the network level as the sum over all its ODspecific market shares $\left(\mathrm{MS}_{\mathrm{ij}}\right)$ in the OD markets $\mathrm{j}$ multiplied by the specific relevance of each $\mathrm{OD}_{\mathrm{j}}$ for airline $\mathrm{i}$. The latter is proxied by the number of passengers of airline $\mathrm{i}$ on $\mathrm{OD}_{\mathrm{j}}\left(\mathrm{PAX}_{\mathrm{ij}}\right)$ divided by the airline's total, network-wide passenger number $\mathrm{PAX}_{\mathrm{i}}^{6}$ :

$$
C P_{i}=\sum_{j=1}^{n}\left(M S_{i j} * P A X_{i j} / P A X_{i}\right) \text { where } M S_{i j}=\frac{P A X_{i j}}{P A X_{j}}
$$

The output of the indicator ranges from the theoretical value of 0.00 to 1.00 . If an airline had a market share of $100 \%$ in all of its OD markets, its CP would take the value of 1 . This would indicate that the carrier was effectively free from any intra-modal competition, subject to the restrictions set above with regard to alternative airports and routes. If a carrier's market shares on most of its ODs were small, the CP index would take a low value.

\section{Numerical example:}

Airline A serves three ODs and carries a total of 600,000 passengers: Munich-Frankfurt (200,000 pax), Frankfurt-Hamburg (100,000 pax), and Munich-Hamburg via Frankfurt (300,000 pax). Other airlines account for 100,000 passengers on Munich-Frankfurt, zero passengers on Frankfurt-Hamburg and 200,000 travellers on Munich-Hamburg.

The competitive position of Airline A then amounts to 0.68 and calculates as follows:

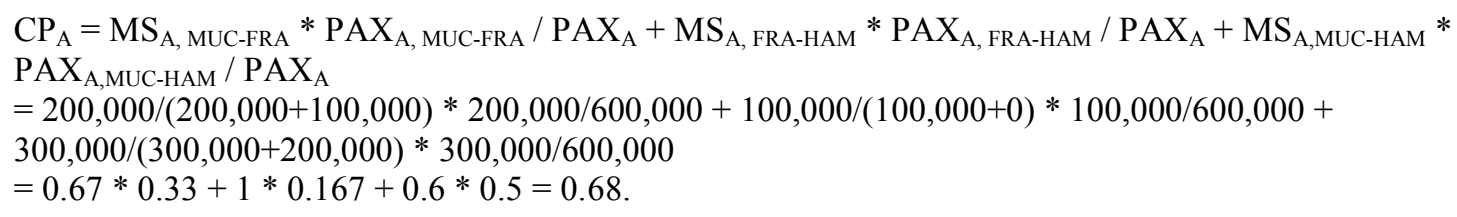

\footnotetext{
${ }^{6}$ Subject to data availability, airline- and origin-destination-specific revenue passenger kilometres (RPK) or total revenues (REV) could also be used to model the airline-specific relevance of each OD.
} 
With the exception of a 10\% sample of airline tickets published by the U.S. Bureau of Transportation Statistics (Airline Origin and Destination Survey DB1B), ${ }^{7}$ which however only covers the US market, OD passenger numbers at airline level are usually not disclosed publicly. Hence, for this paper, monthly passenger figures at the origin-destination and carrier levels were taken from the paid Sabre Market Intelligence (Sabre-MI) database (Sabre, 2014). This database uses MIDT (Marketing Information Data Tapes) booking data from global distribution systems like Sabre, Travelport and Amadeus as its main source of data, combined and adjusted with data from external sources and with estimations for increasingly important direct bookings and for the odd charter operations. Outputs of the Sabre database include leg (passenger numbers and average fares by airline, booking/cabin class and month at the segment, i.e. direct route level) and OD statistics (passenger numbers and average fares at the origin-destination level, as ticketed). ODs (partly) operated by train or coach are included and considered if the train or coach leg is part of the airline ticket, making use of a flight number.

Sabre MI data (or its predecessor, Sabre ADI) have been referred to in a number of research papers and consultancy projects and studies. The quality of the dataset's market size information, e.g. in terms of passenger numbers reported, is usually considered reliable, while it is likely to be less accurate when it comes to fares estimates for markets dominated by LCC with a high share of direct sales. Furthermore, self-connecting passenger flows are not captured by Sabre (e.g., Intervistas, 2014; PWC, 2014). Earlier plausibility checks of the Sabre MI data were also conducted by the author in the context of a number of studies, e.g. in comparing segment- or airport-level passenger numbers reported by Sabre with data from other sources, such as the German Federal Statistical Office or Eurostat. Based on this, the quality of the Sabra dataset seems to increase with aggregation level. In other words, e.g. country-level data tends to be more accurate that (small) city- or routelevel data. This might, in principle, be critical for this work which is based on passenger volumes at the city- and airport-pair level. Nevertheless, for the following reasons, it is reasonable to assume that the quality of the dataset will be sufficient for the purpose of this paper: First, there are no hints for a systematic bias at the expense of specific airlines, which would affect the individual CP results; and second, the analysis is based on a complete collection of all passenger OD-flows within Europe and not on an extrapolation of a small, potentially biased sample.

The actual calculations were performed with Microsoft Excel. To scale the massive amount of data down, September 2015 was chosen as reference and not the full year. September is believed to be a good proxy for the annual average as this month is characterized both by solid business and leisure demand. For this reason, September figures are also used as reference in Airbus' Global market forecast (Airbus, 2017).

For the case study in this paper, only traffic from, to and within the Sabre-MI regions Eastern Europe and Western Europe was taken into account (see Table 1), as we aim at assessing the competitive situations of airlines in the intra-European market. This selection better allows for comparisons between the CPs of LCC (which hardly serve any long haul routes) and the intra-European businesses of the full service network carriers (FSNC).

The Sabre MI region "Eastern Europe" includes basically all of geographical Europe including the whole of Russia, while Turkey is fully excluded. We are aware that geographically large parts of Russia are located in Asia. However, traffic figures for the Asian part of Russia are relatively small as the indicator is based on passenger numbers rather than on revenue passenger kilometers (to which the long flight distances to Far East Russia would contribute relatively stronger). According to traffic data by the Russian Federal Agency of air transport $^{8}, 88 \%$ of the airport traffic at Russia's Top 20 airports in 2015 was handled at airports in the country's European part.

Most traffic within the selected Sabre MI regions takes place in a fully deregulated market environment. However, there might be some markets outside the ECAA where restrictions on market access may still be imposed. As we have no access to exact Governmental agreements on traffic rights, and as those would most likely reveal a range of many different forms of market regulation (from probably very closed markets to almost open market entry), this paper cannot consider OD-specific degrees of market regulation.

\section{Table 1: Definition of Europe}

\footnotetext{
${ }^{7}$ An overview of the dataset is provided here: https://www.transtats.bts.gov/DatabaseInfo.asp?DB_ID=125.

${ }^{8}$ Source: http://www.favt.ru/dejatelnost-ajeroporty-i-ajerodromy-osnovnie-proizvodstvennie-pokazateli-aeroportov-obyom-perevoz/
} 


\begin{tabular}{|l|l|l|l|}
\hline Albania & Denmark & Italy & Poland \\
Armenia & Estonia & Kosovo & Portugal \\
Austria & Faeroe Islands & Latvia & Romania \\
Azerbaijan & Finland & Lithuania & Russian Federation \\
Belarus & France & Luxembourg & Serbia \\
Belgium & Georgia & Macedonia & Slovakia \\
Bosnia And & Germany & Malta & Slovenia \\
Herzegovina & Gibraltar & Moldova & Spain \\
Bulgaria & Greece & Monaco & Sweden \\
Croatia & Hungary & Montenegro & Switzerland \\
Cyprus & Iceland & Netherlands & Ukraine \\
Czech Republic & Ireland & Norway & United Kingdom \\
\hline
\end{tabular}

Source: Sabre MI database. 


\section{Key results and discussion}

\subsection{Perspectives of the analysis}

The calculation of the CP values was first performed at individual airline operator level. As airlines are, however, not always financially or strategically independent from each other and hence cannot always be regarded as competitors, a second iteration was performed at the airline group level, to control for common ownership. For this, a modified dataset was used for which OD passenger numbers had been aggregated to airline groups (Table 2).

Table 2: Airline groups

\begin{tabular}{|l|l|}
\hline Airline Group & Airlines \\
\hline Aeroflot Group & Aeroflot, Rossiya, Orenburg Airlines, Donavia \\
\hline Air Berlin Group & airberlin, NIKI, Belair, LGW \\
\hline $\begin{array}{l}\text { Air France-KLM } \\
\text { AF-KLM) }\end{array}$ & $\begin{array}{l}\text { Air France, Transavia Airlines, Transavia France, Brit Air, KLM, Regional, KLM } \\
\text { Cityhopper }\end{array}$ \\
\hline EasyJet Group & EasyJet, EasyJet Switzerland \\
\hline $\begin{array}{l}\text { International Airline } \\
\text { Group (IAG) }\end{array}$ & British Airways, Iberia (Express), Aer Lingus, Vueling, BA Cityflyer, Open Skies \\
\hline Lufthansa Group & $\begin{array}{l}\text { Lufthansa, Germanwings, SWISS, Austrian, Brussels Airlines, Lufthansa Cityline, } \\
\text { Eurowings, Edelweiss, Air Dolomiti, Tyrolean }\end{array}$ \\
\hline Norwegian & Norwegian Air Shuttle, Norwegian Air International \\
\hline SAS Group & SAS, Blue1, Wideroe \\
\hline Sunexpress & Sunexpress, Sunexpress Germany \\
\hline Thomas Cook & Condor, Thomas Cook Airlines (UK), Condor Berlin, Thomas Cook Airlines Scandinavia \\
\hline TUI & $\begin{array}{l}\text { TUIFly, TUI Airlines Belgium, TUIFly Nordic, Thomson Airways, TUI Airlines } \\
\text { Nederland, Corsair }\end{array}$ \\
\hline
\end{tabular}

In addition, the assessment was not only undertaken at the airport level (incl. train/coach stations with IATA code), but also at the city level, to better reflect the idea that OD level competition may also stem from other origin and/or destination airports serving similar catchments (e.g. Dobruszkes, 2009). Hence, we compiled another dataset at IATA city-code level (see Annex 1). We are aware that, in reality, competition may also come from airports using a different IATA city designator. Such effects, however, could not be modelled here. Table 3 summarizes the four levels of analysis.

Table 3: Different levels of analysis

\begin{tabular}{|l|l|l|l|}
\hline \multicolumn{2}{|c|}{} & \multicolumn{2}{|c|}{ Consideration of airport competition at city level } \\
\cline { 3 - 4 } Consideration of airline common ownership & No & $\begin{array}{l}\text { Airline operator \& } \\
\text { Airport pair level }\end{array}$ & $\begin{array}{l}\text { Airline operator } \\
\text { \& City pair level }\end{array}$ \\
\cline { 3 - 4 } & Yes & $\begin{array}{l}\text { Airline Group } \\
\text { \& Airport pair level }\end{array}$ & $\begin{array}{l}\text { Airline Group } \\
\text { \& City pair level }\end{array}$ \\
\hline
\end{tabular}

In total, the dataset reveals 56.57 Mio. departing intra-European OD travelers for our sample month September 2015. In the following, we report and discuss the CP results for the 30 largest operating carriers and airline groups, respectively. We further differentiate between CP results at the airport pair and at the city pair levels.

\subsection{Airline operator level results}

The analysis was first run at the airline level, regarding each operating airline as a separate player irrespectively of any forms of common ownership (Table 4). The 30 largest airline operators in intra-European OD traffic combined accounted for 42.95 Mio. passengers in September 2015 and hence represented 76\% of the total intraEuropean OD traffic. Interestingly, four of the five largest intra-European aircraft operators were low cost carriers (Ryanair, EasyJet, Vueling and Norwegian), and some formerly big players missed the Top 30, among them Brussels Airlines (428k), Iberia (411k) and Finnair (320k). 
The results at airline operator and airport-pair levels indicate an average, intra-European CP of the Top 30 airlines of 0.58, which however varies between just 0.36 (Monarch) and as much as 0.90 (Wizz Air Hungary). Other airlines with a high CP value include Ryanair, Flybe and Aeroflot ( 0.83 each), followed by EasyJet and Air France (0.71), which means that a large share of the passengers of these airlines have no alternative intramodal travel option between the same origin and destination airports. These results sound logical: Compared to fellow LCC . EasyJet (0.71), Vueling (0.58) or Norwegian (0.61), WIZZ Air and Ryanair still operate many routes from secondary and regional airports that are neither served directly nor indirectly by any other carrier, while the high CP value for Flybe may be explained by the fact that the carrier is a hybrid regional/low cost airline operating from many secondary, niche and regional airports, including those with only short runways that could not be fully used by other carriers.

Table 4: CP results (Airline operator perspective)

\begin{tabular}{|c|c|c|c|c|c|}
\hline \multicolumn{3}{|c|}{ Airline operator perspective } & \multicolumn{3}{|c|}{ Competitive Position (CP) } \\
\hline 3LC & Airline & $\begin{array}{l}\text { \# Departing intra- } \\
\text { European OD Pax } \\
\text { (Sep'15) }\end{array}$ & $\begin{array}{l}\text { Airport- } \\
\text { Pair }\end{array}$ & $\begin{array}{l}\text { City- } \\
\text { Pair }\end{array}$ & Diff. \\
\hline FR & Ryanair & $8,183,422$ & 0.83 & 0.61 & -0.22 \\
\hline $\mathrm{U} 2$ & EasyJet Airline Company Limited & $5,875,534$ & 0.71 & 0.50 & -0.22 \\
\hline VY & Vueling Airlines & $2,521,752$ & 0.58 & 0.51 & -0.06 \\
\hline$\overline{D Y}$ & Norwegian Air Shuttle & $2,419,378$ & 0.61 & 0.52 & -0.09 \\
\hline $\mathrm{LH}$ & Deutsche Lufthansa & $1,872,950$ & 0.52 & 0.47 & -0.04 \\
\hline BA & British Airways & $1,640,341$ & 0.57 & 0.29 & -0.28 \\
\hline $\mathrm{AF}$ & Air France & $1,590,711$ & 0.71 & 0.61 & -0.09 \\
\hline W6 & Wizz Air Hungary & $1,590,321$ & 0.90 & 0.71 & -0.18 \\
\hline SK & Scandinavian Airlines System (SAS) & $1,488,628$ & 0.49 & 0.42 & -0.07 \\
\hline SU & Aeroflot Russian Airlines & $1,472,518$ & 0.83 & 0.44 & -0.39 \\
\hline $\mathrm{AB}$ & Air Berlin & $1,437,270$ & 0.49 & 0.44 & -0.04 \\
\hline $4 \mathrm{U}$ & Germanwings & $1,227,886$ & 0.57 & 0.54 & -0.04 \\
\hline $\mathrm{AZ}$ & Alitalia-Compagnia Aerea Italiana & 961,531 & 0.55 & 0.35 & -0.19 \\
\hline $\mathrm{BE}$ & Flybe & 872,072 & 0.83 & 0.73 & -0.10 \\
\hline EI & Aer Lingus & 777,212 & 0.64 & 0.47 & -0.16 \\
\hline LS & Jet2.com & 757,719 & 0.48 & 0.45 & -0.04 \\
\hline $\mathrm{X} 3$ & Tuifly & 756,003 & 0.41 & 0.40 & -0.02 \\
\hline S7 & Siberia Airlines & 749,225 & 0.60 & 0.35 & -0.25 \\
\hline UN & Transaero Airlines & 723,467 & 0.52 & 0.30 & -0.22 \\
\hline A3 & Aegean Airlines & 713,458 & 0.54 & 0.50 & -0.05 \\
\hline LX & Swiss International Air Lines & 674,253 & 0.45 & 0.41 & -0.04 \\
\hline $\mathrm{ZB}$ & Monarch Airlines & 578,962 & 0.36 & 0.30 & -0.06 \\
\hline $\mathrm{TP}$ & TAP Air Portugal & 562,560 & 0.55 & 0.48 & -0.07 \\
\hline KL & KLM Royal Dutch Airlines & 556,248 & 0.40 & 0.35 & -0.05 \\
\hline UX & Air Europa Lineas Aereas & 541,365 & 0.41 & 0.35 & -0.06 \\
\hline OS & Austrian Airlines AG dba Austrian & 533,360 & 0.46 & 0.43 & -0.02 \\
\hline $\mathrm{HV}$ & Transavia Airlines & 521,133 & 0.69 & 0.68 & -0.01 \\
\hline $\mathrm{DE}$ & Condor Flugdienst & 461,945 & 0.40 & 0.37 & -0.03 \\
\hline UT & Utair Aviation & 451,755 & 0.65 & 0.38 & -0.27 \\
\hline FV & Rossiya Airlines & 440,142 & 0.61 & 0.58 & -0.03 \\
\hline & Sum (Pax) / unweighted average (CP) & $42,953,124$ & 0.58 & 0.47 & \\
\hline
\end{tabular}


The CPs of the largest intra-European network carriers (Lufthansa, British Airways, Air France, SAS, Alitalia), but also smaller ones like TAP Air Portugal or Aegean Airlines end up in a range between $\sim 0.50$ and $\sim 0.70$. Air France (0.71) scores relatively high which seems to stem from a strong position on many French domestic routes and on indirect ODs from smaller places in France. For example, at airport pair level, the dataset shows high market shares for Air France on high-volume ODs from e.g. Paris Orly to Toulouse (82.01\%), Nice (74.69\%), Bordeaux $(\sim 100 \%)$ and Marseille $(\sim 100 \%)$.

Air Berlin, which has gone bankrupt in the meantime, scored lower (0.49) than rival Lufthansa, which may be explained by a higher focus on leisure routes to the Mediterranean which are - in many cases - also offered by low cost or leisure carriers.

Aeroflot is the only network carrier in the Top 30 with a CP exceeding 0.80 . The main reasons for this are supposed to be a) the specialized location of Moscow as a transfer point for indirect traffic flows in Eastern Europe, and b), for ODs from and to Moscow, the large number of exclusively-served routes from Sheremetyevo Airport, while competing Russian airlines as well as many operators from other countries use the airports of Domodedovo or Vnukovo.

Hence, it comes with no surprise that the CPs of Aeroflot (0.83 -> 0.44) and its smaller, Domodedovo-based competitors Siberia (0.60 -> 0.35) and Transaero $(0.52->0.30)$ decline significantly if their CP values are calculated at the more realistic city pair level, assuming that most travelers flying into or out of Moscow may in principle - be willing to use either of these airports. For example, we could identify market shares of close to $100 \%$ for Aeroflot's three biggest routes from Sheremetyevo to St. Petersburg, Simferopol and Sochi, which all plummet to $13-25 \%$ when flights from alternative Moscovian airports like Vnukovo and Domodedovo are considered as competitors. The city level CP value for Transaero, which also ceased operations in the meantime, is especially low as this airline linked Moscow with many "typical" destinations not only within Russia, but also e.g. in Spain or Greece which are also served by other Russian network and holiday carriers.

The same also applies to Ryanair and EasyJet, which often focus on selected airports in multiple-airport cities (e.g. Stansted, Gatwick, or Luton in London, Ciampino in Rome, Charleroi in Brussels, Schoenefeld in Berlin,...). Hence, their CP values also decline if the modelling approach is conducted at the city pair level (Ryanair: 0.83 -> 0.61; EasyJet: 0.71 -> 0.50).

Similarly, given the large number of alternative airports in the London area compared to e.g. Paris, Frankfurt or Munich, the intra-European CP value of British Airways declines much stronger (0.57 ->0.29) than the ones for e.g. Air France $(0.71->0.61)$ or Lufthansa $(0.52->0.47)$ if the city-to-city perspective is taken.

Airlines with $\mathrm{CP}$ values below 50\% have only a minor market share on the average OD relation they serve, which could mean that their fares and revenues are more exposed to competition - although this paper does not contain any assessment of the relation between an airline's CP and its actual pricing power. Prominent examples for airlines with very low CPs come from the leisure segment: The airline with the lowest CPs among the Top 30 was Monarch (0.36 at airport-to-airport level, 0.30 at city-to-city level), which had a high degree of overlapping airport pairs with EasyJet (as Luton and Gatwick are among the biggest bases for both of them) and recently went bankrupt (Forbes, 2017). Other leisure airlines include Condor (0.40/0.37) and TUIFly (0.41/0.40) which both compete with many carriers on routes from Germany to the Mediterranean, Mallorca-based Air Europa $(0.41 / 0.35)$ and UK-based Jet2 (0.48/0.45).

A somewhat surprising result is the relatively low intra-European CP for KLM (0.41/0.35). One explanation may be that Amsterdam is now well served by LCC on direct trunk routes, and that KLM heavily offers indirect connections between the UK and other places in Western Europe, which are often also served by LCC.

\subsection{Airline group level results}

One drawback of the above assessment is the individual airline level perspective, which implies that all other aircraft operators are regarded as competitors. However, in reality, many carriers are part of the same airline group, be it because of mergers, acquisitions or the formation of subsidiaries. Hence, a second model run was done, this time for a modified dataset in which airlines were merged into airline groups (Table 2). For instance, Austrian, Swiss, Brussels Airlines and Germanwings are part of the Lufthansa Group, while International Airline Group (IAG) consists of airlines like British Airways, Iberia (Express), Aer Lingus, Vueling and BA Cityflyer.

The 30 largest independent airlines and airline groups in Europe, as shown in Table 5, together accounted for 50.03 Mio. passengers in September 2015, which equals $88 \%$ of the total intra-European passenger volume. 
Ryanair and EasyJet still head the Top 30 but are now followed by the major, FSNC-led airline groups IAG, Lufthansa Group and Air France-KLM.

Table 5: CP results (Airline group perspective)

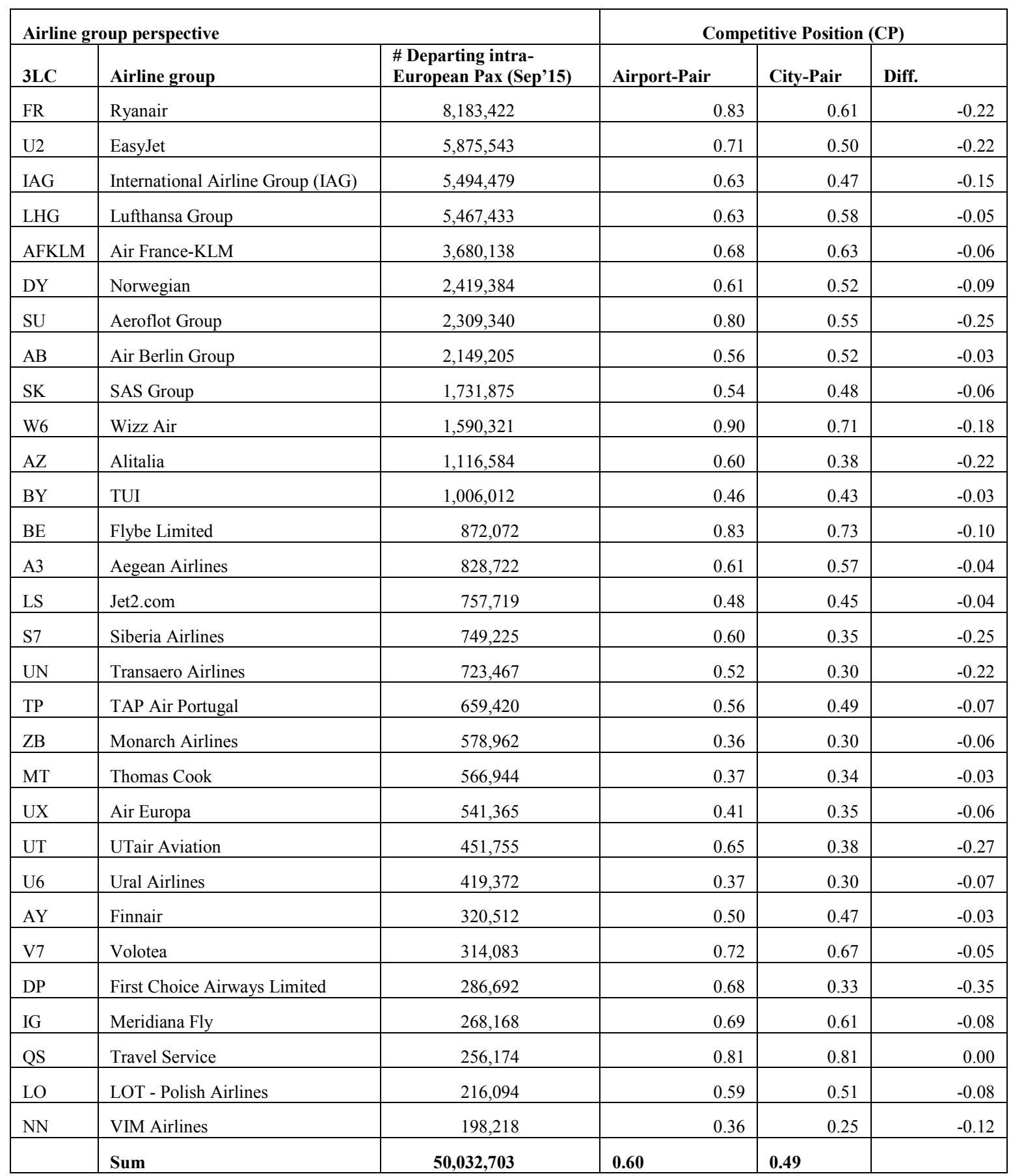

On (unweighted) average, the CP results for the airline groups ( 0.60 from the airport pair perspective versus 0.49 at city pair level) slightly surpass those at airline level ( 0.58 versus 0.47$)$. This observation comes as expected as ODs offered by two or more airlines of the same group are no longer regarded as competing ones. For example, the consolidated market share of Lufthansa Group on the OD from Frankfurt to Vienna amounts to $100 \%$, while the airline-level approach would consider the individual market shares of Lufthansa (51.46\%) and Austrian Airlines (48\%), respectively.

Figure 1 depicts the relationship between airline (group) size and CP value from the city pair perspective, which we regard as more realistic than the airport pair level. For better illustration, different airline business models are 
marked with different symbols ( circle $=$ low cost carrier, diamond $=$ FSNC or airline group dominated by FSNC, square $=$ leisure airline, triangle $=$ other/hybrid airline) .

Figure 1: Competitive Position of Europe's 30 largest airlines and airline groups (city-pair perspective)

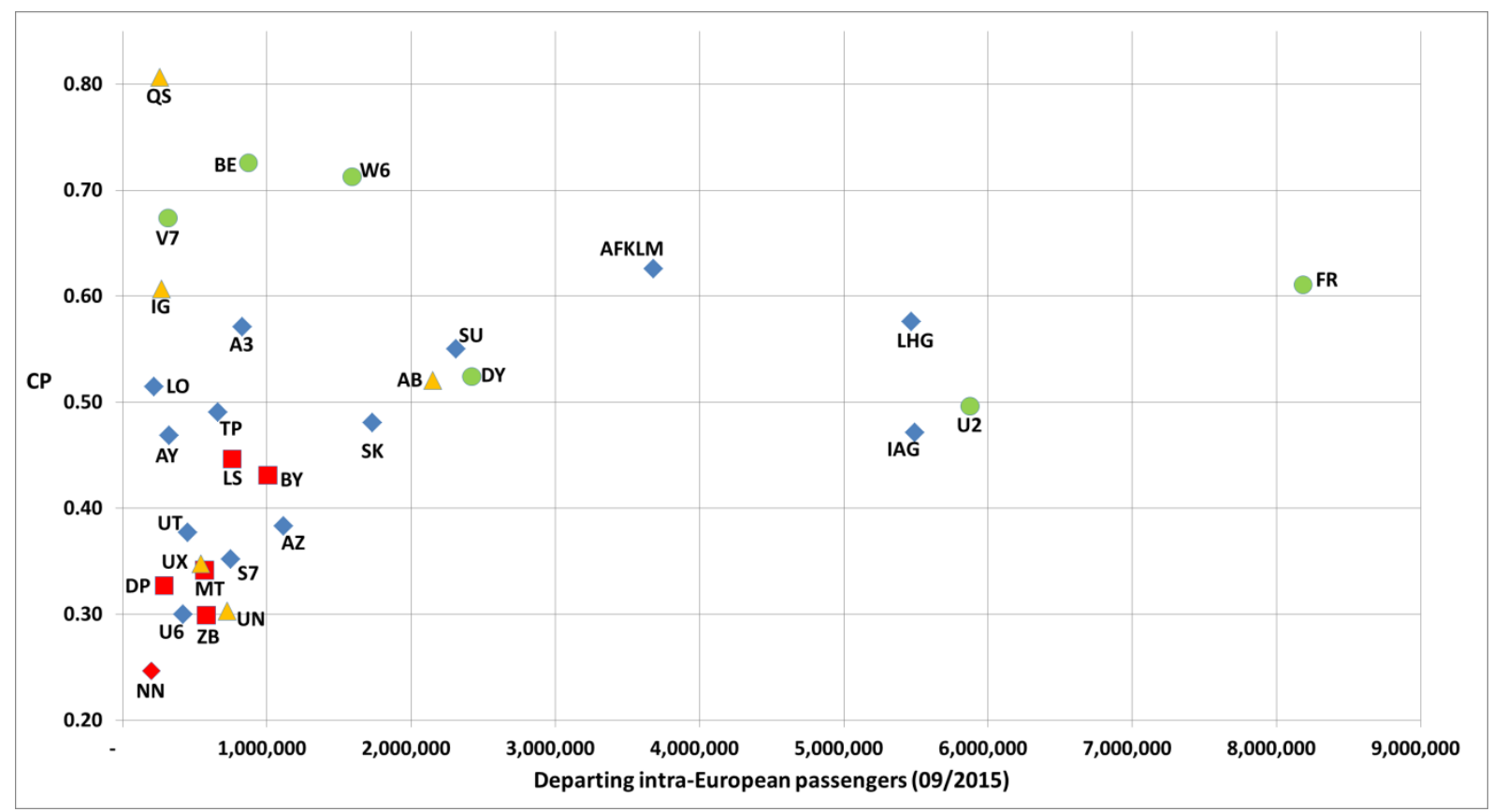

As already indicated in the airline-level discussion above, it shows that low cost carriers (Flybe: 0.73, Wizz Air: 0.71, Volotea: 0.67, Ryanair: 0.61; Norwegian: 0.52, EasyJet: 0.50) tend to achieve relatively higher CP values than the other business models. Especially Flybe, Volotea and Wizzair, three relatively small and specialized LCC, remain above 0.70 , which may be explained by a high share of exclusively served ODs even at city pair level. We count more than 170 city pairs exceeding 2,000 passengers per months on which Wizz Air held a market share of more than $80 \%$, led by Kattowitz-Dortmund (19,490 travelers in September 2015; 99.2\% market share), Budapest-Eindhoven (19,435; 99.5\%) and London-Cluj (19,258; 98.4\%). And Flybe operated about 76 routes with more than 2,000 monthly passengers and a market share exceeding $80 \%$, including BirminghamEdinburgh (23,081 passengers), Birmingham-Glasgow $(18,550)$ and Southampton-Edinburgh $(17,201)$, all with market shares of almost $100 \%$.

The network carriers (including those airline groups that are dominated by a FSNC) account for CP values between 0.3 and 0.63 , whereby the larger players tend to reach CP values of more than 0.50 . The only exception here is IAG (0.47), which is strongly contested by LCC like Ryanair and EasyJet in all of its intra-European key markets (London, Madrid, Barcelona, Dublin). From the city pair perspective, Aeroflot Group (0.55) scores better than Aeroflot alone (0.44 - see Table 4). This is because leading regional carriers in Russia (e.g. Rossiya and Donavia), which account for high market shares on certain routes, are also part of the Aeroflot Group.

As already discussed in Section 4.2, the results again reveal that dedicated leisure airlines and leisure airline groups like TUI (0.43), Jet2.com (0.45), Monarch (0.30), Thomas Cook (0.34) or First Choice (0.33) struggle most to achieve a comfortable competitive position. For TUI and Thomas Cook, the consideration of the whole groups hardly improves the overall CP value, which might be explained by the fact that the individual carriers tend to operate in completely different markets, e.g. TUIFly from Germany, Corsair from France or Thomson Airways from the UK.

Hybrid airlines that are difficult to allocate to ideal-typical business models include Travel Service, Meridiana Fly, Air Berlin or Air Europa. The CP values calculated for these airlines differ immensely. Travel Service (0.81) focuses on nonstop services from Prague under the Smartwings brand, often without any direct competition, while Air Berlin and Air Europa were/are examples for "me-too" carriers combining elements of different business models (holiday flights, long haul flights, intra-European city flights) at a smaller scale than their main rivals Lufthansa and Iberia, respectively. 


\section{Conclusion and Limitations}

Measuring an airline's competitive position is complex as airlines serve many different (direct and indirect) markets with varying degrees of competition. Hence, networks compete against each other, meaning that the "typical" competition assessment at the airport or (direct) route level may not be sufficient in all cases.

Based on traffic flow data at the OD level, this paper presented an approach to assess the CP of airlines and airline groups at the network level, considering the actual competitive situation on each single OD and the relative importance of each OD in relation to the airline's total output in terms of passenger numbers.

Results for Europe for September 2015 indicate that low cost carriers like Ryanair, Wizz Air or Flybe tend to score highest, with $\mathrm{CP}$ values clearly exceeding 50\% in most cases, which means that these carriers reach average market shares of more than $50 \%$ over all ODs they serve. This can be explained by a high(er) share of routes from and to secondary and regional airports, which are not always competed by other carriers.

Dedicated holiday carriers are most exposed to competition, especially from LCC on trunk routes to the Mediterranean. Their CP values usually remain clearly below $50 \%$, while those of the larger network carriers (and respective airline groups), are usually above $50 \%$, but well below those of the above mentioned LCC. The $\mathrm{CP}$ values for smaller network carriers, in contrast, remain below $50 \%$.

Airlines like Ryanair, EasyJet and Aeroflot are examples for carriers that achieve much higher CP values if the assessment is done at the airport pair level and not at the city pair level. The reason for this is that these carriers operate (some of) their main bases in multi-airport cities like London or Moscow where direct route competition is less relevant that competing flights from alternative airports. This suggests that more airport choice in a given region, e.g. achieved through good ground access to alternative airports, will clearly help increasing airline competition.

Our approach might be useful e.g. for policymakers, regulators or analysist and investors. For example, in cartel cases on mergers that might result in route or airport dominance, it could be worth looking at an airline's overall $\mathrm{CP}$ value (and at the simulated CP value for the merged firm) before e.g. imposing route- or airport-specific limitations. Other, topical cases for the application of this approach could be questions such as on the competitive impact of LCC or Gulf carriers on the European network carriers. The latter tend to complain that more and more traffic rights for Gulf carriers would mean more (and unfair) competition for them, but it should be investigated if there really is that much competition at the actually relevant OD levels, given that the focus of FSNC like Lufthansa is on the Europe-North East Asia axis, while Gulf carriers are stronger to e.g. South East Asia and Oceania.

There is a range of limitations to the approach, which could be tackled in future research. First, alternative airports are only considered as competitors if they make use of the same city code. The model could hence be enhanced by a more sophisticated identification of alternative airports, considering actual airport access from relevant catchment areas. The same applies to the consideration of inter-modal competition. Second, while the assessment at the airline group level already helps to depict actual competition between airlines in a more realistic way, the roles and competitive impacts of alliances and joint ventures are not yet considered. While joint ventures hardly play a role in intra-European traffic, they are a common phenomenon on the transatlantic axis (Fabey, 2010) or on routes between e.g. Germany and China (Lufthansa - Air China JV). Third, this paper suggested that the topic might be of relevance e.g. for investors and analysts, but it does not (yet) provide evidence for any correlation between the CP value and an airline's financial position. Finally, a time-series approach could be applied to depict the development of the airline-specific CP values over time.

\section{Acknowledgements}

An early of this paper was presented at the 2016 IAMC Conference. I am thankful for the valuable comments received there, as well as for thoserom the two anonymous reviewers and the guest editor. 


\section{References}

Adler, N. (2001) Competition in a deregulated air transportation market. European Journal of Operational Research, 129, 337-345.

Airbus (2017), Global Horizons 2017-2036, Global Market Forecast.

Alderighi, M., Cento, A., Nijkamp, P., Rietveld, P. (2005) Network competition - the coexistence of hub-andspoke and point-to-point systems. Journal of Air Transport Management, 11, 328-334.

Baker, Jonathan B. (2007), Market definition: An analytical overview, Antitrust Law Journal, 74-1, 129-173.

Barrett, S.D. (2000) Airport competition in the deregulated European aviation market. Journal of Air Transport Management, 6, 13-27.

Berliner Morgenpost (2017) Übernahme von Air Berlin: Am Himmel droht ein Monopol [online] available from $<$ https://www.morgenpost.de/wirtschaft/article212229267/Am-Himmel-droht-ein-Monopol.html $>$ [13 October 2017].

Borenstein, S. (1992) The evolution of U.S. airline competition. Journal of Economic Perspectives, 6, 45-73.

Bowman, C., Faulkner, D. (1994) Measuring product advantage using competitive benchmarking and customer perceptions. Long Range Planning, 27, 119-132.

Bundeskartellamt (2001) Beschluss in dem Kartellverwaltungsverfahren Deutsche Lufthansa AG/Eurowings AG. Gesch.-Z. B 9 - 62100-U-147/00 [online] available from

$<$ http://www.bundeskartellamt.de/SharedDocs/Entscheidung/DE/Entscheidungen/Fusionskontrolle/2001/B9147-00.pdf? _ blob=publicationFile \&v=3> [12 July 2016].

Burghouwt, G., de Wit, J. G. (2015) In the wake of liberalisation: long-term developments in the EU air transport market. Transport Policy, 43, pp. 104-113.

Button, K., McDougall, G. (2006) Institutional and structure changes in air navigation service-providing organizations. Journal of Air Transport Management, 12, 236-252.

Button, K. (2010) Countervailing power to airport monopolies. In: Forsyth, P. et al (Eds), Airport competition, The European Experience, Farnham: Ashgate, 59-75.

Buzzell, R.D., Gale, B.T., Sultan, R.G.M. (1975) Market Share - A Key to Profitability. Harvard Business Review, 53, 97-106.

D’Alfonso, T., Jiang, C., Bracaglia, V. (2016) Air transport and high-speed rail competition: Environmental implications and mitigation strategies. Transportation Research Part A: Policy and Practice, 92, 261-276.

Detzen, D., Jain, P.K., Likitapiwat, T., Rubi, R.M. (2012) The impact of low cost airline entry on competition, network expansion, and stock valuations, Journal of Air Transport Management, 18, 59-63.

Dziedzic, M., Warnock-Smith, D. (2016) The role of secondary airports for today's low-cost carrier business models: The European case. Research in Transportation Business \& Management, 21, 19-32.

Dobruszkes, F. (2009) Does liberalisation of air transport imply increasing competition? Lessons from the European case. Transport Policy, 16, pp. 29-39.

Dobruszkes, F. (2013) The geography of European low-cost airline networks: a contemporary analysis. Journal of Transport Geography, 28, 75-88.

Dobruszkes, F., Givoni, M. , Vowles, T. (2017) Hello major airports, goodbye regional airports? Recent changes in European and US low-cost airline airport choice. Journal of Air Transport Management, 59, 50-62.

Doganis, Rigas (2006), The Airline Business, 2nd ed., London. 
Dresner, M., Windle, R. (1992) Airport Dominance and Yields in the U.S. Airline Industry. Logistics and Transportation Review, 28, 319-339.

Dresner, M. E., Lin, J. S.-C., Windle, R. J. (1996) The impact of low cost carriers on airport and route competition. Journal of Transport Economics and Policy, 30, 309-328.

EU (1992) Council Regulation (EEC) No 2408/92 of 23 July 1992 on access for Community air carriers to intraCommunity air routes.

EU (2006) Decision of the Council and of the Representatives of the Member States of the European Union meeting within the Council 2006/682/EC on the signature and provisional application of the Multilateral Agreement between the European Community and its Member States, the Republic of Albania, Bosnia and Herzegovina, the Republic of Bulgaria, the Republic of Croatia, the former Yugoslav Republic of Macedonia, the Republic of Iceland, the Republic of Montenegro, the Kingdom of Norway, Romania, the Republic of Serbia and the United Nations Interim Administration Mission in Kosovo on the Establishment of a European Common Aviation Area (ECAA)

EU (2016) Directive (EU) 2016/2370 of the European Parliament and of the Council of 14 December 2016 amending Directive 2012/34/EU as regards the opening of the market for domestic passenger transport services by rail and the governance of the railway infrastructure.

Evans, W., Kessides, I. N. (1993) Localized Market Power in the U.S. Airline Industry. The Review of Economics and Statistics, 75, 66-75.

Fabey, M. (2010) Airline joint ventures face big operational challenges, Travel Weekly, Nov 8, 2010, available from http://www.travelweekly.com/Travel-News/Airline-News/Airline-joint-ventures-face-big-operationalchallenges.

FAZ.net (2002) Kartellamt verbietet Lufthansa-Billigflüge [online] available from $<$ http://www.faz.net/aktuell/gesellschaft/luftverkehr-kartellamt-verbietet-lufthansa-billigfluege-150111.html> [12 July 2016].

Forbes (2017) Monarch Airlines Goes Bankrupt, Stranding Thousands Of Travelers Abroad [online] available from <https:/www.forbes.com/sites/grantmartin/2017/10/02/monarch-airlines-goes-bankrupt-strandingthousands-of-travelers-abroad/\#72ad6ac06309> [02 October 2017].

Frenken, K.,Van Terwisga, S.,Verburg, T., Burghouwt, G. (2004) Airline competition at European airports. Tijdschrift voor Economische en Sociale Geografie, 95, 233-242.

Fuellhart, K. (2007) Airport catchment and leakage in a multi-airport region: The case of Harrisburg International. Journal of Transport Geography, 15, 231-244.

Grimaldi, R., Augustin, K., Beria, P. (2017) Intercity coach liberalisation. The cases of Germany and Italy. World Conference on Transport Research - WCTR 2016 Shanghai, 10-15 July 2016. Transportation Research Procedia 25, 474-490.

Grimme, W. (2011) The growth of Arabian airlines from a German perspective - A study of the impacts of new air services to Asia. Journal of Air Transport Management, 17, 333-338.

Grosche, T., Klophaus, R. (2015) Hubs at risk: Exposure of Europe's largest hubs to competition on transfer city pairs. Transport Policy, 43, 55-60.

Intervistas (2014) Viability Assessment of Long Haul Service at Wellington Airport [online] available from $<$ http://www.connectwellington.co.nz/static/documents/Technical\%20Report\%202.pdf> [07 June 2018].

Lian, J.I., Rønnevik, J. (2011) Airport competition - Regional airports losing ground to main airports. Journal of Transport Geography, 19, 85-92.

Lieshout, R., Malighetti, P., Redondi, R., Burghouwt, G. (2016) The competitive landscape of air transport in Europe. Journal of Transport Geography. 50, 68-82. 
Lijesen, M., Rietveld, P., Nijkamp, P. (2001) Hub Premiums in European Civil Aviation. Transport Policy, 8, 193-199.

Maertens, S. (2012) Estimating the market power of airports in their catchment areas - a Europe-wide approach. Journal of Transport Geography, 22, 10-18.

Maertens, S., Pabst, H., Grimme, W. (2016) The scope for low-cost connecting services in Europe - Is selfhubbing only the beginning? Research in Transportation Business \& Management, 21, 84-93.

Obermeyer, A., Evangelinos, C., Püschel, R. (2013) Price dispersion and competition in European airline markets. Journal of Air Transport Management, 26, 31-34.

O'Connell, J.F., Bueno, O.E. (2016) A study into the hub performance Emirates, Etihad Airways and Qatar Airways and their competitive position against the major European hubbing airlines, Journal of Air Transport Management, in press, http://dx.doi.org/10.1016/j.jairtraman.2016.11.006.

Pels, E. (2008) Airline network competition: Full-service airlines, low-cost airlines and long-haul markets. Research in Transportation Economics, 24, 68-74.

PWC (2014) Overview of air transport and current and potential air connectivity gaps in the CESE region Paper B [online] available from

$<$ https://ec.europa.eu/transport/sites/transport/files/modes/air/studies/doc/internal_market/2014-12-overview-ofair-transport-and-current-and-potential-air-connectivity-gaps-in-the-cese-region-paper-b.pdf $>$ [07 June 2018].

Reynolds-Feighan, A. (2001) Traffic distribution in low-cost and full-service carrier networks in the US air transportation market. Journal of Air Transport Management, 7, 265-275.

Sabre (2014) Sabre AirVision Market Intelligence, Version 5.7. User Guide.

Socorro, M.P., Betancor, O., de Rus, G. (2018) Feasibility and desirability of airport competition: The role of product substitutability and airlines' nationality. Journal of Air Transport Management, 67, 224-231.

Veldhuis, J. (1997) The competitive position of airline networks. Journal of Air Transport Management, 3, 181188.

Williamson, O.E. (1972) Dominant firms and the monopoly problem: market failure considerations. Harvard Law Review, 85, 1512-1531. 
Annex 1: Airports sharing the same IATA city code

\begin{tabular}{|c|c|c|c|}
\hline $\begin{array}{l}\text { Origin } \\
\text { Airport }\end{array}$ & Origin Airport Name & Origin City Name & Origin Country Name \\
\hline BFS & Belfast International Apt & Belfast & United Kingdom \\
\hline BHD & Belfast City Apt & Belfast & United Kingdom \\
\hline TXL & Berlin Tegel Apt & Berlin & Germany \\
\hline SXF & Berlin Schonefeld Apt & Berlin & Germany \\
\hline CRL & Brussels South Charleroi Airport & Brussels & Belgium \\
\hline BRU & Brussels National Airport & Brussels & Belgium \\
\hline OTP & Bucharest Otopeni Apt & Bucharest & Romania \\
\hline PSA & Florence Pisa Airport & Florence & Italy \\
\hline FLR & Florence Amerigo Vespucci & Florence & Italy \\
\hline FRA & Frankfurt International Apt & Frankfurt & Germany \\
\hline HHN & Frankfurt Hahn Airport & Frankfurt & Germany \\
\hline GLA & Glasgow International Airport & Glasgow & United Kingdom \\
\hline PIK & Glasgow Prestwick Apt & Glasgow & United Kingdom \\
\hline GOT & Gothenburg Landvetter Apt & Gothenburg & Sweden \\
\hline GSE & Gothenburg Saeve Apt & Gothenburg & Sweden \\
\hline HAM & Hamburg Fuhlsbuettel Airport & Hamburg & Germany \\
\hline LBC & Hamburg Luebeck Airport & Hamburg & Germany \\
\hline IEV & Kiev Zhulyany Apt & Kiev & Ukraine \\
\hline KBP & Kiev Borispol Apt & Kiev & Ukraine \\
\hline STN & London Stansted Apt & London & United Kingdom \\
\hline LHR & London Heathrow Apt & London & United Kingdom \\
\hline LGW & London Gatwick Apt & London & United Kingdom \\
\hline LTN & London Luton Apt & London & United Kingdom \\
\hline LCY & London City Apt & London & United Kingdom \\
\hline LYS & Lyon Saint Exupery Apt & Lyon & France \\
\hline GNB & Lyon Grenoble Saint Geoirs Apt & Lyon & France \\
\hline LYN & Lyon Bron Apt & Lyon & France \\
\hline MAN & Manchester International Apt & Manchester & United Kingdom \\
\hline LPL & Liverpool & Manchester & United Kingdom \\
\hline MXP & Milan Malpensa Apt & Milan & Italy \\
\hline LIN & Milan Linate Apt & Milan & Italy \\
\hline BGY & Milan Orio Al Serio & Milan & Italy \\
\hline PMF & Milan Parma Apt & Milan & Italy \\
\hline MSQ & Minsk International Apt 2 & Minsk & Belarus \\
\hline MHP & Minsk International Apt 1 & Minsk & Belarus \\
\hline DME & Moscow Domodedovo Apt & Moscow & Russia \\
\hline SVO & Moscow Sheremetyevo Apt & Moscow & Russia \\
\hline VKO & Moscow Vnukovo Apt & Moscow & Russia \\
\hline BSL & Euroairport Basel & Mulhouse/Basel & Switzerland \\
\hline MLH & Euroairport Mulhouse & Mulhouse/Basel & Switzerland \\
\hline MUC & Munich International Airport & Munich & Germany \\
\hline AGB & Munich Augsburg Apt & Munich & Germany \\
\hline
\end{tabular}




\begin{tabular}{|l|l|l|l|}
\hline EMA & Nottingham East Midlands Airport & Nottingham & United Kingdom \\
\hline NQT & Nottingham Airport & Nottingham & United Kingdom \\
\hline OSL & Oslo Airport & Oslo & Norway \\
\hline ORY & Oslo Torp Airport & Oslo & Norway \\
\hline CDG & Paris Orly Apt & Paris & France \\
\hline BVA & Paris Charles De Gaulle Apt & Paris & France \\
\hline KEF & Reykjavik Keflavik Apt & Paris & France \\
\hline RKV & Reykjavik Apt & Reykjavik & Iceland \\
\hline FCO & Rome Fiumicino Apt & Reykjavik & Iceland \\
\hline CIA & Rome Ciampino Apt & Rome & Italy \\
\hline SCS & Shetland Islands Scatsta Apt & Rome & Italy \\
\hline LSI & Shetland Islands Sumburgh Apt & Shetland Islands & United Kingdom \\
\hline LWK & Shetland Islands Lerwick/Tingwall Apt & Shetland Islands & United Kingdom \\
\hline ARN & Stockholm Arlanda Apt & Stockholm & Sweden \\
\hline BMA & Stockholm Bromma Apt & Stockholm & Sweden \\
\hline NYO & Stockholm Skavsta Airport & Stockholm & Sweden \\
\hline VST & Stockholm Vasteras Apt & Stockholm & Sweden \\
\hline TFN & Tenerife Norte Apt & Tenerife & Spain \\
\hline TFS & Tenerife Sur Reina Sofia Apt & Tenerife & Spain \\
\hline VCE & Venice Marco Polo Apt & Venice & Italy \\
\hline TSF & Venice Treviso Apt & Venice & Italy \\
\hline SOurport & Shille & \\
\hline
\end{tabular}

Source: Sabre MI database. 